Note

\section{High-Pressure Sterilization of Ice Nucleation-active Bacterial Cells}

\author{
Michiko Watanabe, Takahiro Makino, ${ }^{*}$ \\ Keiko KumENo** and Soichi AraI*** \\ Faculty of Education, Tokyo Gakugei University, \\ Koganei-shi, Tokyo 184; Japan \\ * Shizuoka Agricultural Experiment Station, \\ Iwata-gun, Shizuoka 438, Japan \\ ** Department of Food and Nutrition, \\ Japan Women's University. \\ Bunkyo-ku, Tokyo 112, Japan \\ *** Department of Agricultural Chemistry, \\ The University of Tokyo, \\ Bunkyo-ku, Tokyo 113, Japan
}

Received August 27, 1990

Ice nucleation active (INA)-bacteria are able to freeze water at a subzero temperature above $-5^{\circ} \mathrm{C} .{ }^{1-5)}$ The ability of INA bacteria may be stronger than that of any other ice nuclei ever known. ${ }^{3)}$ In nature, INA bacterial cells and their fragments cause frost injury to crops and, therefore, most investigations have been directed towards finding methods for lowering or inhibiting their activity. ${ }^{6-10}$ On the other hand, INA bacterial cells are practically applicable; a commercial product is available as a snow inducer. ${ }^{11)}$ In this case, the cells of Pseudomonas syringae are sterilized by beta-irradiation and then freeze-dried.

We have proposed methods for applying INA bacterial cells as effective ice nuclei to the freeze texturing, ${ }^{10}$ freeze-drying $^{12}$, and freeze-concentration ${ }^{13)}$ of food materials. In these cases, sterilization of the products is necessary if living cells are used. Hayashi et al. ${ }^{14)}$ have proposed that high pressure can be used to kill microorganisms. The application of high pressure to the sterilization of such INA bacteria as Erwinia ananas may thus be possible. This paper deals with the high-pressure sterilization of $E$. ananas cells for practical applications.

E. ananas $\mathrm{IN}-10^{4)}$ was cultured at $20^{\circ} \mathrm{C}$ for $48 \mathrm{hr}$ in a medium containing bactotrypton (Difco, $10 \mathrm{~g}$ ), proteose peptone No. 3 (Difco, $10 \mathrm{~g}$ ), dipotassium phosphate $(1.5 \mathrm{~g}$ ), magnesium sulfate $(1.5 \mathrm{~g})$ and glycerol $(10 \mathrm{~g})$ in water (1 $1)$, the cels then being collected by centrifugation at $8,000 \times g$ for $20 \mathrm{~min}$. Aliquots of the collected cells were suspended in $10 \mathrm{~mm}$ phosphate buffered saline $(\mathrm{pH} \mathrm{7})$, $10 \mathrm{~mm}$ acetate buffered saline (pH 3), $10 \mathrm{~mm}$ carbonate buffered saline $(\mathrm{pH} 9)$ and water at a population density of $10^{8} \mathrm{cells} / \mathrm{ml}$ in each. Each suspension was packed in a plastic bottle and then compressed to $2000-5000 \mathrm{~kg} / \mathrm{cm}^{2}$ by a pressure generator (Hikari Koatsu, KP5B) at $20^{\circ} \mathrm{C}$ for $10 \mathrm{~min}$. The cell paste obtained by the centrifugation process already mentioned was subjected again to a similar pressure treatment. The pressure-treated cells were diluted with autoclaved physiological saline and then cultured on Pseudomonas agar (Difco) at $20^{\circ} \mathrm{C}$ for $48 \mathrm{hr}$. Viability is expressed as the living cell number/g of sample.

Table I shows that the cells were sterilized at a

Table I. Viability of E. ananas TREATED BY Different Pressures at $20^{\circ} \mathrm{C}$

\begin{tabular}{|c|c|c|c|c|c|}
\hline \multirow{2}{*}{$\begin{array}{c}\text { State of cells } \\
\text { in the pressure } \\
\text { treatment }\end{array}$} & \multirow{2}{*}{$\begin{array}{c}\text { Living } \\
\text { cell } \\
\text { number } \\
\text { before } \\
\text { pressure } \\
\text { treating }\end{array}$} & \multicolumn{4}{|c|}{ Pressure $\left(\mathrm{kg} / \mathrm{cm}^{2}\right)$} \\
\hline & & 2,000 & 3,000 & 4,000 & 5,000 \\
\hline & & \multicolumn{4}{|c|}{$\begin{array}{c}\text { Viability } \\
\text { (living cell number/g) }\end{array}$} \\
\hline \multicolumn{6}{|l|}{ Suspension } \\
\hline at $\mathrm{pH} 7$ & $1 \times 10^{8}$ & $9 \times 10^{6}$ & $\begin{array}{l}<10 \\
<10\end{array}$ & $<10$ & $<10$ \\
\hline at $\mathrm{pH} 9$ & $1 \times 10^{8}$ & $8 \times 10^{6}$ & $<10$ & $<10$ & $<10$ \\
\hline in water & $1 \times 10^{8}$ & $7 \times 10^{6}$ & $<10$ & $<10$ & $<10$ \\
\hline $\begin{array}{l}\text { in FC-lemon } \\
\text { juice* } \\
\text { (solid: } 24 \% \text { ) }\end{array}$ & $2 \times 10^{6}$ & $2 \times 10^{4}$ & $<10$ & $<10$ & $<10$ \\
\hline $\begin{array}{l}\text { in FC-lemon } \\
\text { juice* } \\
\text { (solid: } 36 \% \text { ) }\end{array}$ & $3 \times 10^{6}$ & $2 \times 10^{4}$ & $<10$ & $<10$ & $<10$ \\
\hline Paste & $>10^{12}$ & $6 \times 10^{10}$ & $<10$ & $<10$ & $<10$ \\
\hline
\end{tabular}

* Freeze-concentrated lemon juice.

Table II. ICE-NUCLEATION ACTIVITY OF E. ananas TREATEd BY A Pressure of $3,000 \mathrm{~kg} / \mathrm{cm}^{2}$ FOR $10 \mathrm{MIN}$ AT $20^{\circ} \mathrm{C}$

\begin{tabular}{ccc} 
& \multicolumn{2}{c}{ Degree of supercooling $\left({ }^{\circ} \mathrm{C}\right)$} \\
\cline { 2 - 3 } $\begin{array}{c}\text { State of cells } \\
\text { in the pressure } \\
\text { treatment }\end{array}$ & $\begin{array}{c}\text { Immediately } \\
\text { after } \\
\text { treating }\end{array}$ & $\begin{array}{c}24 \mathrm{hr} \text { after } \\
\text { treating }\end{array}$ \\
\hline Suspension & & \\
at pH 3 & $>5$ & $3.3 \pm 1.2$ \\
at pH 7 & $>5$ & $1.6 \pm 1.4$ \\
at pH 9 & $>5$ & $2.2 \pm 2.0$ \\
in water & $>5$ & $1.5 \pm 1.3$ \\
Paste & $>5$ & $1.3 \pm 1.2$ \\
Freeze-dried* & - & $1.7 \pm 1.6$
\end{tabular}

* The cell paste was compressed at the pressure, allowed to stand at $0^{\circ} \mathrm{C}$ for 1 day, and then freezedried. 
hydrostatic pressure of more than $3,000 \mathrm{~kg} / \mathrm{cm}^{2}$ in all of the media used. The cells were also sterilized in a paste state when they were treated at more than $3,000 \mathrm{~kg} / \mathrm{cm}^{2}$ for $10 \mathrm{~min}$. The result suggests that the cells can be applied with no hygiene problems to food processes such as freeze texturing, freeze-drying and freeze concentration following a high-pressure sterilization at $3,000 \mathrm{~kg} / \mathrm{cm}^{2}$.

A water suspension $(2 \mathrm{ml})$ of each sample containing $10^{8}$ cells was measured for its ice-nucleation activity according to the method in the previous paper. ${ }^{10)}$ The ice-nucleation activity is expressed as the degree of supercooling (melting temperature minus nucleating temperature). ${ }^{10}$ The pressure treatment of the cells under all the environments tested resulted in decreasing their ice-nucleation activity to a degree of supercooling of more than $5^{\circ} \mathrm{C}$. However, the cells regained high activity by chilling at $0^{\circ} \mathrm{C}$ for one day (Table II). Next, the sterilized cell paste was allowed to stand at $0^{\circ} \mathrm{C}$ for 1 day and then freeze-dried. The freeze-dried product also possessed high ice-nucleation activity (Table II). The result suggests that the product can be supplied as ice nuclei for industrial uses.

An application study was carried out to concentrate fresh lemon juice by the use of INA bacterial cells. Two freeze-concentrated lemon juice samples with solid contents of $24 \%$ and $36 \%$ were produced, using the bacterial cells according to the method in the previous paper. ${ }^{13)}$ Subsequently, each of the samples was treated at $2000-5000 \mathrm{~kg} / \mathrm{cm}^{2}$ for $10 \mathrm{~min}$ at $20^{\circ} \mathrm{C}$ and then the viability of the cells was determined. As shown in Table I the cells were totally killed at more than $3000 \mathrm{~kg} / \mathrm{cm}^{2}$. The lemon juice samples treated at $3000 \mathrm{~kg} / \mathrm{cm}^{2}$ were submitted to gas chromatography to determine the limonen and citral contents according to the method in the previous paper. ${ }^{13)}$ An area ratio of limonen to citral $(\mathrm{L} / \mathrm{C})$ was used to evaluate the freshness in flavor. ${ }^{13)}$ Calculated $\mathrm{L} / \mathrm{C}$ ratios were $8.63,8.61$ and 8.63 for the raw material, the pressure-treated sample with a solid content of $24 \%$, and that with a solid content of $36 \%$, respectively. A sensory test by a panel of five trained members showed that the flavor of each pressure-treated sample was not significantly different from that of the original material.

Acknowledgments. We are grateful to Dr. R. Hayashi of the Research Institute of Food Science at Kyoto University for his technical support.

\section{References}

1) L. R. Maki, E. L. Galyon, M. Chang-Cien and D. R. Caldwell, Appl. Microbiol., 28, 456 (1974).

2) S. S. Hirano, E. A. Maher, S. E. Lindow, A. Kelman and C. D. Upper, Phytopathol. News, 12, 176 (1978).

3) S. E. Lindow, Ann. Rev. Phytopathol., 21, 363 (1983).

4) M. Goto, B. L. Huang, T. Makino, T. Goto and T. Inaba, Ann. Phytopathol. Soc. Jpn., 54, 189 (1988).

5) H. Obata, Y. Saeki, J. Tanishita, H. Hori and Y. Higashi, Agric. Biol. Chem., 51, 1761 (1987).

6) D. C. Amy, S. E. Lindow and C. D. Upper, Nature, 262, 282 (1976).

7) S. E. Lindow, D. C. Amy and C. D. Upper, Phytopathology, 68, 523 (1978).

8) S. E. Lindow, D. C. Amy and C. D. Upper, Appl. Environ. Microbiol., 36, 831 (1978).

9) S. A. Yankofsky, Z. Levin and A. Moshe, Curr. Microbiol., 5, 213 (1981)

10) S. Arai and M. Watanabe, Agric. Biol. Chem., 50, 169 (1986).

11) Eastman Kodak Co., Internationale Seilbahn-Rundschau, 7(11), 4 (1988).

12) M. Watanabe and S. Arai, Agric. Biol. Chem., 51, 557 (1987).

13) M. Watanabe, J. Watanabe, K. Kumeno, N. Nakahama and S. Arai, Agric. Biol. Chem., 53, 2731 (1989).

14) R. Hayashi, "Use of High Pressure in Food," ed. by R. Hayashi, San-Ei Shuppan, Kyoto, 1989, pp. 1-30. 